Review

\title{
Femtosecond Laser Processing of Biodegradable Polymers
}

\author{
Mitsuhiro Terakawa ${ }^{1,2}$ \\ 1 Department of Electronics and Electrical Engineering, Keio University, Yokohama 223-8522, Japan; \\ terakawa@elec.keio.ac.jp; Tel.: +81-45-566-1737 \\ 2 School of Integrated Design Engineering, Keio University, Yokohama 223-8522, Japan
}

Received: 12 June 2018; Accepted: 9 July 2018; Published: 11 July 2018

\begin{abstract}
Biodegradable polymers have attracted increasing attention in tissue engineering and drug delivery systems owing to their high biocompatibility and biodegradability. Among the various methods for shape forming and modification of biodegradable polymers, laser processing has advantages in a dry processing approach that can process complex-shaped surfaces without using toxic chemical components. This review provides an overview of femtosecond laser processing of biodegradable polymers, especially in the last decade. The interaction mechanism of femtosecond laser pulse and biodegradable polymers, e.g., bond dissociation after laser irradiation, affects the degradable property of biodegradable polymers, which has the potential to control the degradation and sustainability of a structure. Applied studies on controlling cell behavior, tissue scaffolding, and drug release are also described.
\end{abstract}

Keywords: laser processing; femtosecond laser; biodegradable polymers

\section{Introduction}

Cells, growth factors, and scaffolds are essential elements for the regeneration of a three-dimensional (3D) structure in tissue engineering. Tissue scaffolds play a role as a matrix for cell proliferation until the tissue is regenerated. Consequently, biodegradable polymers are considered promising materials for tissue scaffolding because of their degradable properties. Repeated surgery for the removal of the scaffold is not necessary after tissue regeneration if the degradation of the scaffold in a body can be controlled for an appropriately sustained period of time. The biocompatibility of biodegradable polymers is comparably high, which realizes the translation of the materials into practical medical applications such as bone fixation material and sutures. To maximize the utility and potential of biodegradable polymers, technologies to fabricate the material into an arbitrary shape, i.e., processing technologies, are crucial. In particular, customization in shape forming is required in many cases in biomedical applications to fabricate tailored products for patients. Laser processing enables such tailored fabrication because of its suitability for computer-aided scanning and processing without a mold, which shows great potential for use in the technological transition from mass production to mass customization.

Laser processing of biodegradable polymers has many advantages in addition to its simple processing. A chemical solvent, whose residue may be toxic for the human body, is not necessary for laser-based fabrication. Additional microstructuring in the localized area is easy to perform even after the formation of a general shape. Because many biodegradable polymers show large optical absorption in ultraviolet (UV) wavelengths and less absorption at visible to near-infrared wavelengths, lasers oscillating at UV wavelengths have been used for processing in cases of nanosecond laser-based fabrication [1-4]. Kancharla et al. in 2001 reported the laser ablation of polyvinyl alcohol by using an $\mathrm{XeCl}$ excimer laser (308 $\mathrm{nm}$ in wavelength) and fourth harmonics generation (FHG) of 
a Nd:YAG laser (266 nm in wavelength) [1]. They reported that the heat-affected zone (HAZ) was relatively smaller while using UV wavelengths. Lazare et al. formed porous structures composed of micrometer-sized bubbles on the surface of collagen, chitosan, and polyvinylpyrrolidone (PVP) by using a $\mathrm{KrF}$ excimer laser $(248 \mathrm{~nm}$ ) [4]. However, because femtosecond lasers enable the processing of transparent materials via nonlinear optical interaction, femtosecond lasers have opened up new avenues to fabricate three-dimensional (3D) structures with visible and near-infrared wavelengths.

The degradation rate of biodegradable polymers depends on the crystallinity and composed micro- and nanostructures. Biodegradability can be changed by laser irradiation because laser pulses induce the scission of chemical bonding. In addition, laser processing enables the formation of not only entire shapes but also micro- and nano-sized substructures. Recently, considerable attention has been given to laser-based surface structuring of biopolymers for tissue engineering and for drug delivery systems because of these advantages.

In this review, the fundamentals and applications of femtosecond laser processing of biodegradable polymers are described by reviewing previous studies. A significant increase in the number of papers on femtosecond laser processing of biodegradable polymers has been seen in the last decade. Laser processing properties are introduced, along with micro- and nanostructuring, changes in biodegradability by laser irradiation, and experimental demonstrations for potential applications.

\section{Femtosecond Laser Processing of Biodegradable Polymers}

Soon after the rise of research on femtosecond laser processing, pioneering studies on femtosecond laser ablation of polymers have been reported. Initial studies, including those using polymethyl methacrylate, were performed with femtosecond lasers oscillating at UV wavelength [5,6], but, thanks to the high peak intensity of a femtosecond laser pulse, it is now widely known that polymers that show less linear optical absorption in visible to near-infrared wavelengths can be processed via nonlinear optical interaction by using femtosecond lasers [7,8]. Precise three-dimensional (3D) structures can be fabricated, not only on the surface of a material, but also in its interior. Furthermore, the ultrashort interaction time of the femtosecond laser pulse and a material realizes much smaller HAZ, even for the processing of polymers that have low glass-transition and melting temperatures. These advantages are promising for processing biodegradable polymers. Table 1 lists publications on femtosecond laser processing of biodegradable polymers.

Table 1. Ultrashort pulse laser processing of biodegradable polymers.

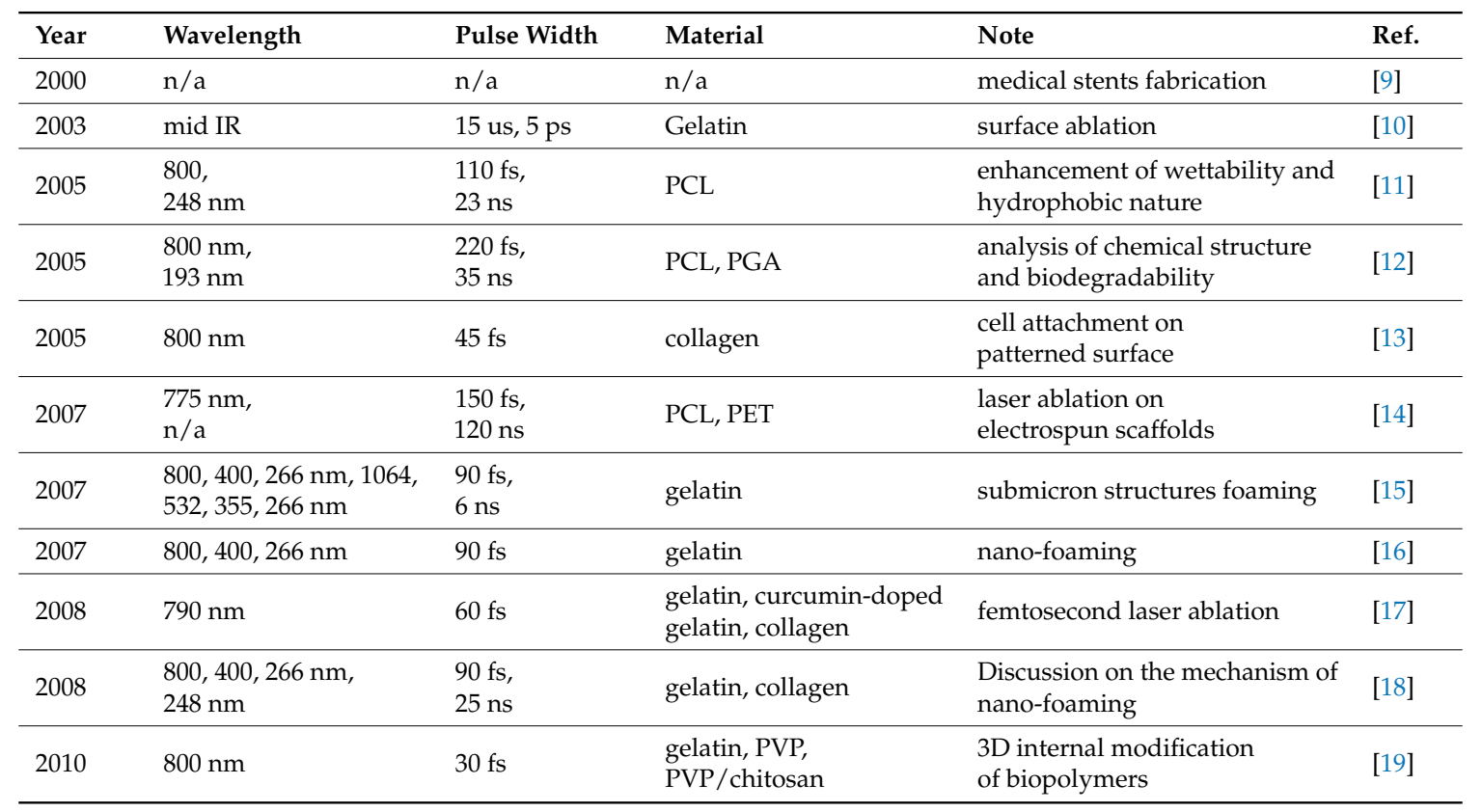


Table 1. Cont.

\begin{tabular}{|c|c|c|c|c|c|}
\hline Year & Wavelength & Pulse Width & Material & Note & Ref. \\
\hline 2010 & $800 \mathrm{~nm}$ & $150 \mathrm{fs}$ & PCL, PLA & evaluation of HAZ & [20] \\
\hline 2010 & $800 \mathrm{~nm}$ & $150 \mathrm{fs}$ & PLLA-PCL copolymer & $\begin{array}{l}\text { evaluation of cell alignment on } \\
\text { direct laser written surface }\end{array}$ & [21] \\
\hline 2011 & $800 \mathrm{~nm}$ & $20 \mathrm{fs}$ & PLA & 3D scaffold fabrication & [22] \\
\hline 2011 & $775 \mathrm{~nm}$ & $150 \mathrm{fs}$ & PCL/gelatin & $\begin{array}{l}\text { micro-patterned electrospun } \\
\text { scaffold and cell behavior }\end{array}$ & [23] \\
\hline 2011 & $775 \mathrm{~nm}$ & $150 \mathrm{fs}$ & PCL & $\begin{array}{l}\text { effect of micro-channel on } \\
\text { cell behavior }\end{array}$ & [24] \\
\hline 2011 & $1064 \mathrm{~nm}$ & $10 \mathrm{ps}$ & PLLA & $\begin{array}{l}\text { effect of crystallinity on } \\
\text { micro-grating fabrication }\end{array}$ & [25] \\
\hline 2011 & $800 \mathrm{~nm}$ & $150 \mathrm{fs}$ & PLA-PCL & $\begin{array}{l}\text { effect of laser patterned surface } \\
\text { on up regulation of } \\
\text { myogenic markers }\end{array}$ & [26] \\
\hline 2012 & $800 \mathrm{~nm}$ & $100 \mathrm{fs}$ & PLLA & $\begin{array}{l}\text { effect of laser processed } \\
\text { electrospun scaffolds on } \\
\text { cell behavior }\end{array}$ & [27] \\
\hline 2012 & $800 \mathrm{~nm}$ & $120 \mathrm{fs}$ & PLGA & micro-vessel scaffold fabrication & [28] \\
\hline 2012 & $\begin{array}{l}248 \mathrm{~nm}, \\
213 \mathrm{~nm}, \\
248 \mathrm{~nm}\end{array}$ & $\begin{array}{l}20 \mathrm{~ns}, \\
150 \mathrm{ps}, 500 \mathrm{fs}\end{array}$ & $\begin{array}{l}\text { chitosan, starch, } \\
\text { chitosan/starch }\end{array}$ & $\begin{array}{l}\text { effect of pulse duration on } \\
\text { porous surface fabrication }\end{array}$ & [29] \\
\hline 2013 & $800 \mathrm{~nm}$ & $150 \mathrm{fs}$ & PLA-PCL & $\begin{array}{l}\text { nano/micro-grating and } \\
\text { cell behavior }\end{array}$ & [30] \\
\hline 2014 & $1064 \mathrm{~nm}$ & $10 \mathrm{ps}$ & PLLA, PS & $\begin{array}{l}\text { micro-patterned surface for } \\
\text { cancer cell confinement }\end{array}$ & [31] \\
\hline 2014 & $800 \mathrm{~nm}$ & $30-100 \mathrm{fs}$ & $\begin{array}{l}\text { Gelatin, collagen, } \\
\text { collagen-elastin }\end{array}$ & $\begin{array}{l}\text { porous structure in ablation } \\
\text { area, cell proliferation. }\end{array}$ & [32] \\
\hline 2014 & $1030,515 \mathrm{~nm}$ & $400-800 \mathrm{fs}$ & PLLA, Poly(D,L-lactid) & $\begin{array}{l}\text { high repetition rate up to } \\
500 \mathrm{kHz}\end{array}$ & [33] \\
\hline 2015 & $\begin{array}{l}520 \mathrm{~nm}, \\
532 \mathrm{~nm}\end{array}$ & $\begin{array}{l}350 \mathrm{fs}, \\
10 \mathrm{ps}\end{array}$ & PLLA, PLGA & parameter dependence & [34] \\
\hline 2015 & $800 \mathrm{~nm}, 400 \mathrm{~nm}$ & $100 \mathrm{fs}$ & PLLA & LIPSS formation & [35] \\
\hline 2015 & $775 \mathrm{~nm}$ & $200 \mathrm{fs}$ & PLGA, PPP & $\begin{array}{l}\text { femtosecond laser ablation and } \\
\text { MAPLE for cell adhesion }\end{array}$ & [36] \\
\hline 2015 & $1040 \mathrm{~nm}$ & $115 \mathrm{fs}$ & PLA & $\begin{array}{l}\text { processing in air and in water, } \\
\text { high-rep rate of } 57 \mathrm{MHz}\end{array}$ & [37] \\
\hline 2016 & $515 \mathrm{~nm}$ & $400 \mathrm{fs}$ & PLLA electrospun fibers & $\begin{array}{l}\text { fibrous platforms for cell } \\
\text { adhesion and direction }\end{array}$ & [38] \\
\hline 2016 & $800 \mathrm{~nm}$ & $30 \mathrm{fs}$ & $\begin{array}{l}\text { Collagen/elastin } \\
\text { blends, gelatin }\end{array}$ & $\begin{array}{l}\text { laser ablation for changing cell } \\
\text { adhesion and wettability }\end{array}$ & [39] \\
\hline 2016 & $800 \mathrm{~nm}, 400 \mathrm{~nm}$ & $100 \mathrm{fs}$ & PLGA & $\begin{array}{l}\text { biodegradability depending on } \\
\text { the laser wavelength }\end{array}$ & [40] \\
\hline 2016 & $515 \mathrm{~nm}$ & $450 \mathrm{fs}$ & PLLA & $\begin{array}{l}\text { experimental optimization of } \\
\text { laser parameters }\end{array}$ & [41] \\
\hline 2017 & $800 \mathrm{~nm}, 400 \mathrm{~nm}$ & $100 \mathrm{fs}$ & PLGA & $\begin{array}{l}\text { release of loaded molecules after } \\
\text { laser ablation }\end{array}$ & [42] \\
\hline 2017 & $266 \mathrm{~nm}$ & $\begin{array}{l}100 \mathrm{fs}, \\
5 \mathrm{~ns}\end{array}$ & PLGA, PLLA & comparison of fs and ns lasers & [43] \\
\hline 2017 & $1030 \mathrm{~nm}$ & $180 \mathrm{fs}$, & PLA & nano-void formation & [44] \\
\hline 2018 & $800,275 \mathrm{~nm}$ & $85 \mathrm{fs}$ & PLA & comparison of six polymers & [45] \\
\hline 2018 & $800 \mathrm{~nm}$ & $30 \mathrm{fs}$ & chitosan & texturing for bio-interfaces & [46] \\
\hline 2018 & $800 \mathrm{~nm}$ & $30 \mathrm{fs}$ & PCL & osteoblast cell adhesion & [47] \\
\hline 2018 & $515 \mathrm{~nm}$ & $450 \mathrm{fs}$ & PLLA & $\begin{array}{l}\text { detailed study on } \\
\text { physicochemical properties }\end{array}$ & [48] \\
\hline
\end{tabular}


A considerable number of publications have been reported since the year 2000. One of the pioneering works was the fabrication of a biodegradable stent by using a femtosecond laser, which was reported by Tönshoff et al. They reported that the HAZ with femtosecond laser ablation was $1 / 10$ the size of that using a $\mathrm{CO}_{2}$ laser [9]. Although the details, including the material, were not described in the paper, the result showing the precise structure was sufficient to indicate the great potential of femtosecond lasers for polymer processing. Aguilar et al. compared the results of an 800-nm femtosecond laser with those from a 193-nm nanosecond laser and reported that a smaller HAZ was observed in the case of the femtosecond laser, indicating the precise processing of the material [12]. As for a picosecond laser, Ortiz et al. reported the laser ablation of poly-L-lactic acid (PLLA) by comparing the fundamental wave $(1064 \mathrm{~nm})$, the second harmonic generation (SHG) wave $(532 \mathrm{~nm})$, and the third harmonic generation (THG) wave $(355 \mathrm{~nm})$ of $\mathrm{Nd}: \mathrm{YVO}_{4}$ laser [25]. They reported that laser ablation is governed by a multiphoton process in all cases, and UV wavelengths exhibited efficient laser ablation.

Interestingly, scission of bonds after laser ablation is different for a case with femtosecond laser pulses compared to that with nanosecond laser pulses, even for the same wavelength [43]. Figure 1 shows the C1s narrow scan XPS spectra of polylactic-co-glycolic acid (PLGA) (Figure 1a) and PLLA (Figure 1b). A wavelength of $266 \mathrm{~nm}$ was used for both cases, with femtosecond laser pulses and nanosecond laser pulses. The THG from a Ti:sapphire chirped pulse amplification (CPA) laser system (pulse duration $100 \mathrm{fs}$ ) (Coherent Inc., California, CA, USA) was used as the femtosecond laser pulse, whereas the FHG from a Q-switched Nd:YAG laser (pulse duration $5 \mathrm{~ns}$ ) was used as the nanosecond laser pulse. As can be seen in Figure 1, although the peak at $289 \mathrm{eV}$ remained relatively unchanged following nanosecond laser irradiation, the peak significantly decreased following femtosecond laser irradiation. Because the bond energy of a $\mathrm{C}=\mathrm{O}$ bond $(7.5 \mathrm{eV})$ is higher than the photon energy at $266 \mathrm{~nm}$ $(4.65 \mathrm{eV})$, two-photon absorption at the irradiation of intense femtosecond laser pulses contributed to induce $\mathrm{C}=\mathrm{O}$ bond dissociation. The difference between a nanosecond laser and a femtosecond laser can also be seen for different crystallinities of the polymers after laser irradiation. Figure 2 shows the XRD spectra of PLLA. Peaks in the XRD spectra of PLLA decreased in height following laser irradiation, and were significant with femtosecond laser pulse irradiation. The differences in the results of bond dissociation after laser irradiation affect the degradable property of biodegradable polymers, which will be described in the next section.
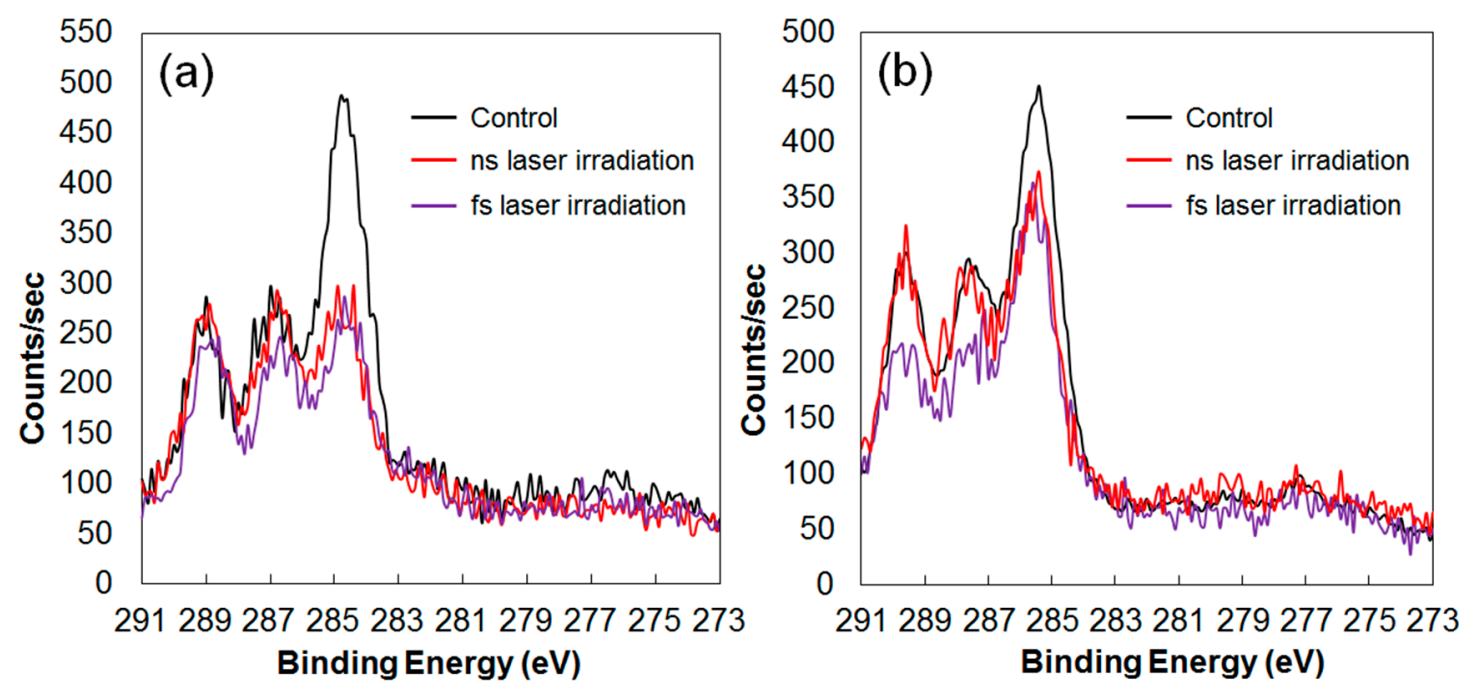

Figure 1. C1s narrow scan XPS spectra for the surface of PLGA films (a) and PLLA films (b). Black, red, and purple lines indicate non-irradiated films (control), films irradiated with a nanosecond laser, and films irradiated with a femtosecond laser, respectively. A wavelength of $266 \mathrm{~nm}$ was used for both cases with femtosecond laser pulses and nanosecond laser pulses. 


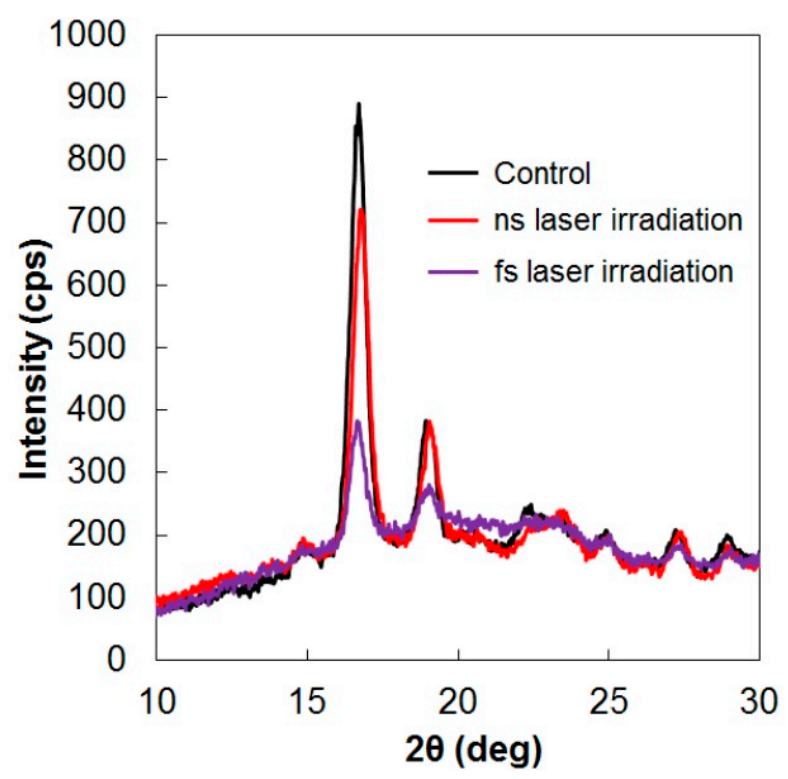

Figure 2. XRD spectra for the surface of PLLA films. Black, red, and purple lines indicate non-irradiated films (control), films irradiated with a nanosecond laser, and films irradiated with a femtosecond laser, respectively. A wavelength of $266 \mathrm{~nm}$ was used for both cases femtosecond laser pulses and nanosecond laser pulses.

\section{Degradable Property after Laser Irradiation}

The degradable property of biodegradable polymers affects the durability and biocompatibility of the fabricated structure in addition to the sustainability of the structure in practical applications. Controlling the degradation property is one of the keys to effective utilization, which may depend on the applications and patients. The biodegradation of a biodegradable polymer in a physiological environment proceeds via the hydrolysis of ester bonds in the presence of absorbed water. The degradation rate of a biodegradable polymer can be influenced by several factors including molecular weight, crystallinity, surface morphology, and surface hydrophilicity. Several methods have been proposed to control these factors, such as annealing [49], copolymerization [50], porous structure formation [51], and light-based modification [52-55]. Laser-based methods enable high spatial selective modification, which provides localized changes in the biodegradable property, even after molding. Because the change in biodegradable properties by laser irradiation is an emerging technology, papers describing the direct evaluation on biodegradable properties are limited, although the crystallinity, molecular weight, and bond dissociation after laser irradiation have been studied widely. In 2005, a study on the change in biodegradation rate by laser processing was reported. Aguilar et al. studied the laser ablation of polycaprolactone (PCL) and polyglycolic acid (PGA) by using ArF excimer laser (wavelength $193 \mathrm{~nm}$ ) [12]. They reported the scission of chemical bonds and the generation of CO and $\mathrm{CO}_{2}$ gases, which was analyzed by X-ray photoelectron spectroscopy (XPS). Laser-irradiated PCL exhibited a high degradation rate compared to non-irradiated PCL, whereas PGA showed no significant change in degradation rate. Controlling the degradation rate was also attempted by taking advantage of the thermal effect of laser pulse because the degradation rate of the biodegradable polymers depends largely on the molecular structure. Laser pulses comparable to or longer than nanoseconds have been used for obtaining thermal effects, i.e., laser annealing. By using a laser, the annealing depth can be controlled by changing the wavelength. Because of the different penetration depths in a material, there is high spatial controllability of both the depth and the irradiated area, since the laser irradiation area is easily controlled by the beam diameter and laser scanning. Hsu et al. investigated the decrease in the crystallinity of PLLA after laser pulse irradiation (wavelength $248 \mathrm{~nm}$, pulse duration $25 \mathrm{~ns}$ ), which was evaluated by wide-angle X-ray diffraction (WAXD) [54]. 
On the basis of the decrease in the ratio of $\mathrm{O} 1 \mathrm{~s}$ to $\mathrm{C} 1 \mathrm{~s}$ peaks, they discussed the dissociation of $\mathrm{C}-\mathrm{O}$ bonds and the possible emission of oxygen atoms from the film in the form of $\mathrm{CO}$ and $\mathrm{CO}_{2}$. Slepička et al. reported a decrease in the wettability of PLLA with laser fluence and number of pulses; the latter has a more significant influence [56].

Femtosecond laser processing of biodegradable polymers has advantages in 3D precise processing; however, detailed studies on the effects of femtosecond laser irradiation on the degradable property are limited to a few cases. Our group found different degradation rates of the biodegradable polymer after femtosecond laser ablation, which depends on the laser wavelength [40]. Figure 3 shows a comparison of laser ablation craters on a PLGA surface at different times after irradiation with 800-nm and 400-nm femtosecond laser pulses. Laser fluences and number of pulses were carefully selected to fabricate laser ablation craters of the same diameter to minimize the initial difference in the diameter. A crater fabricated by mechanical milling is also shown for comparison. The crater fabricated by femtosecond laser pulses at $800 \mathrm{~nm}$ in wavelength showed no significant change in diameter after $48 \mathrm{~h}$ of immersion in phosphate-buffered saline (PBS), whereas that by $400-\mathrm{nm}$ femtosecond laser pulses exhibited comparably rapid expansion over an immersion period, indicating the acceleration of degradation. The acceleration of degradation can also be confirmed by the mass change. As shown in Figure 4, there was a significant decrease in the mass of the samples irradiated by $400 \mathrm{~nm}$ laser pulses. These results demonstrate the potential of femtosecond laser processing for controlling the degradation rate after form shaping and structuring by selecting a suitable wavelength.

The degradation rate of a biodegradable polymer after laser irradiation has been explained by the decrease in crystallinity associated with surface melting, and in molecular weight owing to the photolysis of chemical bonds. Because PLGA is a polymer with less crystallinity, with the wavelength of $400 \mathrm{~nm}$, the significant acceleration of the biodegradation in the case of PLGA [40] is attributable to the decrease in molecular weight induced by the chemical bond dissociation rather than the change in crystallinity.

(a)
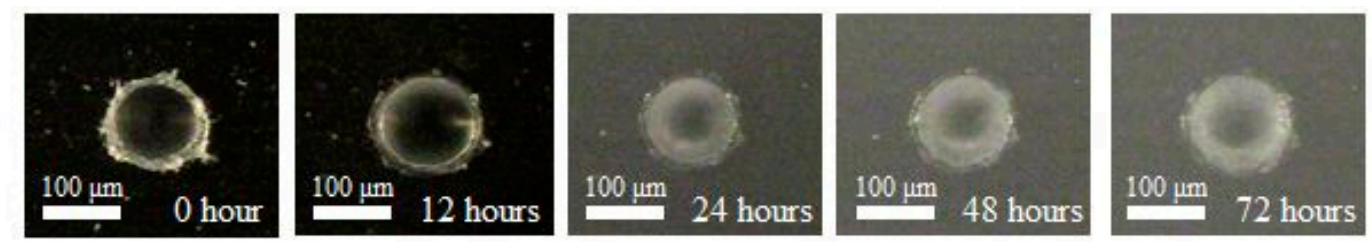

(b)
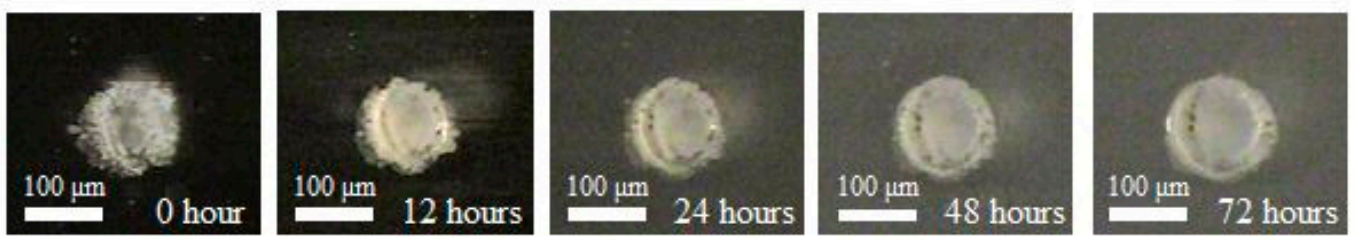

(c)
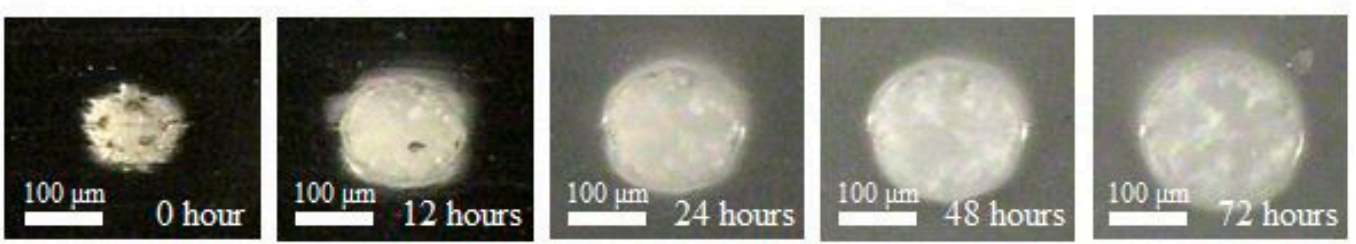

Figure 3. Digital microscopic images of craters formed on PLGA films. The time shown in each figure indicates the time of the samples immersed in PBS at $37^{\circ} \mathrm{C}$. (a) Crater formed by mechanical milling. (b) Laser ablation crater under the condition of $800 \mathrm{~nm}$ wavelength, $1.0 \mathrm{~J} / \mathrm{cm}^{2}, 15,000$ pulses. (c) Laser ablation crater under the condition of $400-\mathrm{nm}$ wavelength, $0.15 \mathrm{~J} / \mathrm{cm}^{2}, 15,000$ pulses. Laser fluences were carefully selected to fabricate laser ablation craters of the same diameter to minimize the initial difference in the diameter. 


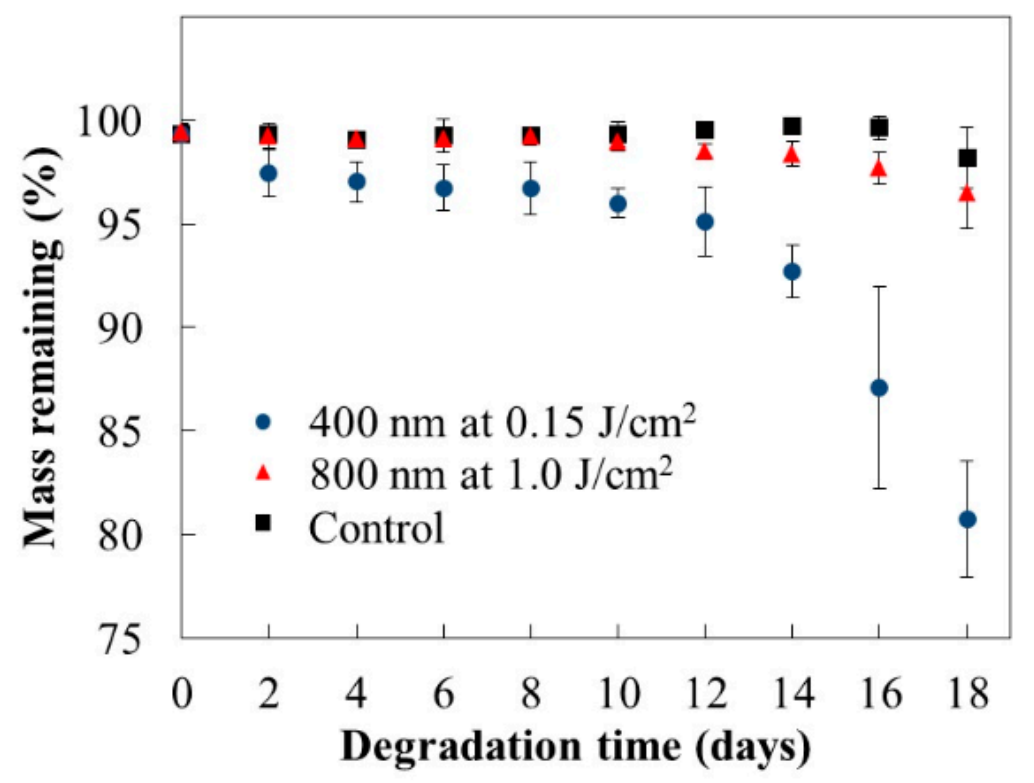

Figure 4. Mass of PLGA films remaining during degradation. Closed squares, red triangles, and closed blue circles indicate PLGA films without laser irradiation, PLGA films irradiated at $800 \mathrm{~nm}$, and PLGA films irradiated at $400 \mathrm{~nm}$, respectively.

\section{Formation of Laser-Induced Periodic Surface Structure (LIPSS) on the Surface of Biodegradable Polymers}

Laser-induced periodic surface structure (LIPSS) is a unique nanostructure formed by laser irradiation of multiple pulses at laser fluence under or near the threshold of single-pulse laser ablation. Because an LIPSS can be formed in the laser-irradiated area with unfocused or loosely focused laser pulses, a large area can be treated, i.e., the formation throughput of subwavelength periodic structures is comparably high. Many studies on LIPSS formation on metals, dielectrics, and semiconductors have been reported. The formation of LIPSS on titanium [57] and titanium oxide [58] has been studied for enhancing the adhesion of cells and alignment toward biomedical applications. Studies on LIPSS formation on the surface of polymers can be traced back to a publication in 1985 [59]; however, investigations with biodegradable polymers are limited to a few cases. Pérez et al. demonstrated the formation of LIPSS on chitosan and polyvinylpyrrolidone, highly water-soluble biodegradable polymers [60]. They used nanosecond laser pulses at wavelengths of 193, 213, and $266 \mathrm{~nm}$; therefore, linear absorption was the dominant interaction.

Periodic structures formed on a PLLA surface by using femtosecond laser pulses are shown in Figure 5. Scanning electron microscopy (SEM) images are shown for the cases of 800, 400, and $266 \mathrm{~nm}$ for comparison. At $800 \mathrm{~nm}$, LIPSS was rarely formed only under limited experimental conditions (Figure 5a). The structure perpendicular to the laser polarization had a 149-nm average periodicity, much shorter than the laser wavelength. Figure 5b shows LIPSS formed with a 400-nm laser wavelength. Compared to the case at $800 \mathrm{~nm}$, LIPSS perpendicular to the polarization was formed at wide laser fluence and pulse duration conditions. Because the photon energy at $400 \mathrm{~nm}$ is higher than at $800 \mathrm{~nm}$, the number of photons necessary for multiphoton absorption is smaller at $400 \mathrm{~nm}$, resulting in the facilitation of Coulomb explosion or bond dissociation mediated by Norrish type II reaction. The LIPSS, which has a slight curvature, was mostly formed on the peripheral part of the ablation crater. Unlike the cases at $800 \mathrm{~nm}$ and $400 \mathrm{~nm}$, the LIPSS formed at $266 \mathrm{~nm}$ (Figure 5c) was quite shallow and had no dependency on the polarization. The mechanism of LIPSS formation may be different for the 266-nm case. Photomechanical pressure by the thermal effect of laser pulses possibly contributed to LIPSS formation. 


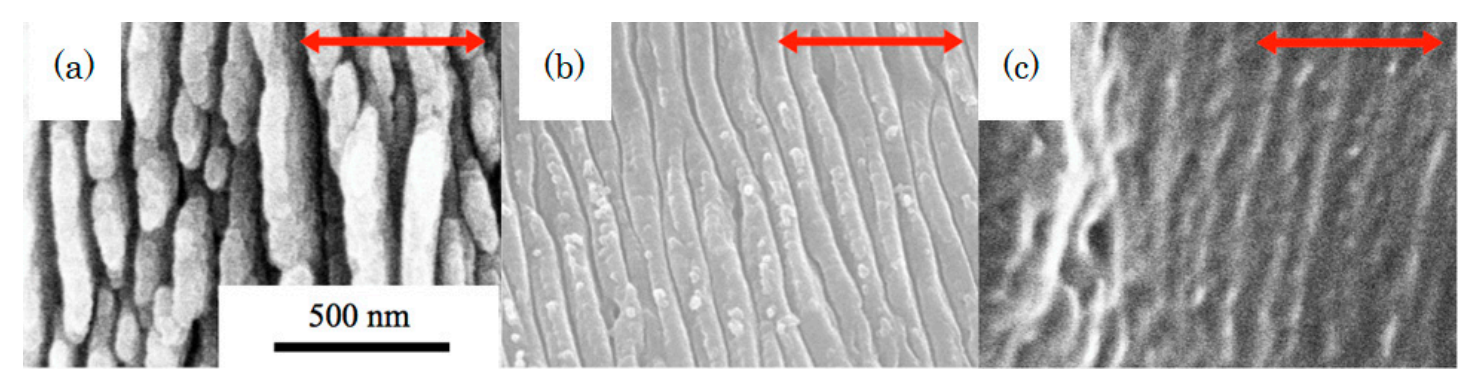

Figure 5. LIPSS formed on the PLLA surface by the irradiation of femtosecond laser pulses at different wavelengths. (a) $800 \mathrm{~nm}, 1.0 \mathrm{~J} / \mathrm{cm}^{2}, 3000$ pulses; (b) $400 \mathrm{~nm}, 0.4 \mathrm{~J} / \mathrm{cm}^{2}, 5000$ pulses; (c) $266 \mathrm{~nm}$, $7.5 \mathrm{~mJ} / \mathrm{cm}^{2}, 5000$ pulses. Red double-headed arrows indicate the polarization direction.

\section{Cell Adhesion and Behavior on the Laser-Irradiated Surface of Biodegradable Polymers}

Cell behavior is affected by the surface micro- and nanostructure of the biodegradable polymers, as well as their wettability. Because the ultrashort laser pulse enables processing of transparent polymers, several studies on the fabrication of micro- and nanostructures on the surface of biodegradable polymers have been reported toward controlling cell behavior. Yeong et al. reported the attachment and alignment properties of mouse myoblasts on the surface of PLLA-PCL, in which microchannels were formed by $800-\mathrm{nm}$ femtosecond laser pulses [21]. The cells exhibited attachment in the channels, and a high degree of alignment was observed. It was also reported that the microchannels with topographic micropatterns on a PLLA-PCL substrate fabricated by femtosecond laser ablation promote upregulation of several hallmark markers associated with myogenesis for human mesenchymal stem cells (hMSCs) cultured on a scaffold with microchannels [26]. In 2014, Ortiz et al. reported an investigation on the effect of micropattern on the proliferation and morphology of breast cancer cells. They reported that the pattern direction directly affected cell proliferation, leading to the guided growth of cell clusters along that direction [31]. The structure suitable for controlling cell behavior is not limited to microchannels. Castillejo et al. compared UV femtosecond and nanosecond laser pulses to form porous structures on chitosan, starch, and their blended films. Femtosecond laser pulses of $248 \mathrm{~nm}$ yield a porous, foamy superficial layer on the film surface, in which cells are likely to proliferate on the structured surface [29]. Jun et al. showed that fibrous platforms with patterned hierarchical topographies fabricated by femtosecond laser ablation can regulate myoblast behavior (Figure 6) [38]. Cell behavior is closely related to the surface wettability. Toosi et al. reviewed the femtosecond laser processing parameters on the surface morphology and the wettability [61].

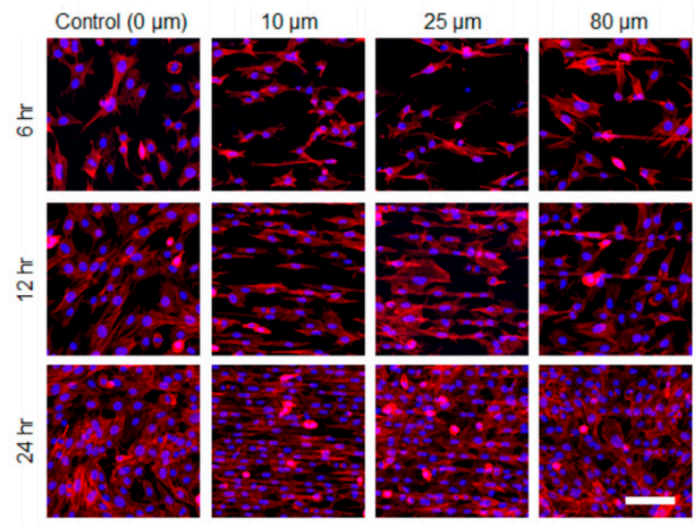

Figure 6. Effect of laser-ablated groove patterns on the adhesion and shape transition of C2C12 myoblasts. Scale bar indicates $100 \mu \mathrm{m}$. Reproduced with permission from [38], [ACS Applied Materials \& Interfaces]; published by [ACS Publications], [2016]. 


\section{Laser-Triggered Molecular Release from Biodegradable Polymers}

Because the degradation rate of biodegradable polymers can be enhanced by laser irradiation, laser-triggered release and laser-controlled-sustained release of drug molecules have been investigated. Laser-based methods, among other methods, have advantages in spatial characteristics and applicability to catheter-based systems using optical fibers. Most studies for controlling molecular release using lasers take advantage of metal nanoparticles as an absorber [62] because many polymers show little absorption of visible and near-infrared light. A limited number of papers reported molecular release without doping materials. Hsu et al. studied the release of embedded fluorescence molecules from biodegradable polymers using nanosecond laser pulses at a wavelength of $248 \mathrm{~nm}$ [63]. The acceleration of molecular release by the degradation was reported (Figure 7). They found that laser irradiation decreased the crystallinity of the polymer surface, resulting in the acceleration of release. As for studies using femtosecond lasers, Umemoto et al. reported that femtosecond laser irradiation at $400 \mathrm{~nm}$ wavelength accelerates the release of loaded-fluorescent molecules from PLGA, whereas $800 \mathrm{~nm}$ laser irradiation does not induce a comparable degree of change in the release of loaded molecules [42]. This may be due to the different degree of change in the degradation rate depending on the laser wavelength, as described in Section 3. Ariyasu et al. reported the burst release of embedded molecules triggered by femtosecond laser pulses [64]. The release of fluorescence molecules encapsulated in biodegradable microcapsules was significantly enhanced by laser irradiation. The rupture of biodegradable microcapsules was also observed after laser irradiation.

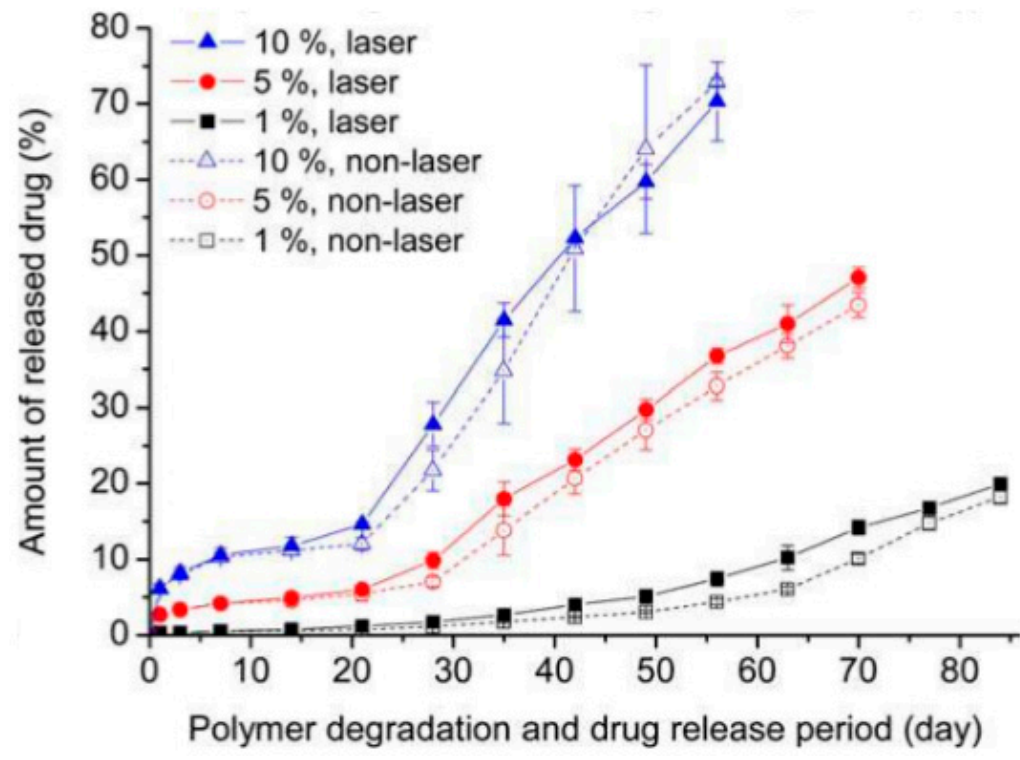

Figure 7. Drug release profiles of laser-treated and non-laser-treated matrices. Reproduced with permission from [63], [ACS Applied Materials \& Interfaces]; published by [ACS Publications], [2016].

\section{Conclusions and Perspectives}

The interaction of femtosecond lasers and biodegradable polymers can be discussed using laser interaction with polymers; however, laser irradiation induces changes in the degradation rate of biodegradable polymers, which is unique and interesting from the point of view of the mechanism and applications. Previous studies revealed that the degradation rate is different depending on the femtosecond laser wavelength, and the difference is attributable to the difference in chemical bond dissociation. The difference in chemical bond dissociation is closely related to nonlinear interaction and physics with intense femtosecond laser pulses; however, further study is necessary to reveal the mechanism in detail. By controlling the degradation rate of biodegradable polymers, attractive applications will be realized such as control of the residual time of tissue scaffolds, controlled molecular 
release of drug molecules for drug delivery systems, and sustained release of insulin for the treatment of diabetes. Lasers provide high spatial controllability and highly precise structuring, which are expected to help realize sophisticated biomedical devices. In addition, recent progress in femtosecond laser processing such as cooled laser ablation [65], Bessel beam [66], etc. has the potential to fabricate a much more precise and desirable structure.

Acknowledgments: The author is grateful to Shuhei Yada, Akimichi Shibata, Taiga Umemoto, and Naonari Kondo for their contributions to the research in our group related to laser processing of biodegradable polymers.

Conflicts of Interest: The author declares no conflict of interest.

\section{Abbreviations}

$\begin{array}{ll}\text { CPA } & \text { chirped pulse amplification } \\ \text { FHG } & \text { fourth harmonics generation } \\ \text { HAZ } & \text { heat affected zone } \\ \text { LIPSS } & \text { laser induced periodic surface structure } \\ \text { PCL } & \text { polycaprolactone } \\ \text { PGA } & \text { polyglycolic acid } \\ \text { PLLA } & \text { poly-L-lactic acid } \\ \text { PLGA } & \text { polylactic-co-glycolic acid } \\ \text { PPP } & \text { polylactide-polyethylene glycol-polylactide } \\ \text { PVP } & \text { polyvinylpyrrolidone } \\ \text { SEM } & \text { scanning electron microscopy } \\ \text { SHG } & \text { second harmonics generation } \\ \text { THG } & \text { third harmonics generation } \\ \text { UV } & \text { ultraviolet } \\ \text { WAXD } & \text { wide-angle X-ray diffraction } \\ \text { XPS } & \text { X-ray photoelectron spectroscopy } \\ \text { XRD } & \text { X-ray diffraction } \\ \text { 3D } & \text { three-dimensional }\end{array}$

\section{References}

1. Kancharla, V.V.; Chen, S. Laser micromachining of a biodegradable polymer. Trans. NAMRI/SME 2001, 29, 407-412.

2. Chen, S.; Kancharla, V.V.; Lu, Y. Laser-based microscale patterning of biodegradable polymers for biomedical applications. Int. J. Mater. Prod. Technol. 2003, 18, 457-468. [CrossRef]

3. Rytlewski, P.; Mróz, W.; Żenkiewicz, M.; Czwartos, J.; Budner, B.J. Laser induced surface modification of polylactide. Mater. Process. Technol. 2012, 212, 1700-1704. [CrossRef]

4. Lazare, S.; Tokarev, V.; Sionkowska, A.; Wiśniewski, M. Surface foaming of collagen, chitosan and other biopolymer films by $\mathrm{KrF}$ excimer laser ablation in the photomechanical regime. Appl. Phys. A 2005, 81, 465-470. [CrossRef]

5. Küper, S.; Stuke, M. Femtosecond UV excimer laser ablation. Appl. Phys. B 1987, 44, 199-204. [CrossRef]

6. Srinivasan, R.; Sutcliffe, E.; Braren, B. Ablation and etching of polymethylmethacrylate by very short (160 fs) ultraviolet (308 nm) laser pulses. Appl. Phys. Lett. 1987, 51, 1285-1287. [CrossRef]

7. Krüger, J.; Kautek, W. Ultrashort pulse laser interaction with dielectrics and polymers. Adv. Polym. Sci. 2004, 168, 247-289. [CrossRef]

8. Sima, F.; Sugioka, K.; Vazquez, R.M.; Osellame, R.; Kelemen, L.; Ormos, P. Three-dimensional femtosecond laser processing for lab-on-a-chip applications. Nanophotonics 2018, 7, 613-647. [CrossRef]

9. Toenshoff, H.K.; Ostendorf, A.; Nolte, S.; Korte, F.; Bauer, T. Micromachining using femtosecond lasers. Proc. SPIE 2000, 4088, 136-139. [CrossRef]

10. Heya, M.; Fukami, Y.; Nagats, H.; Nishida, Y.; Awazu, K. Gelatin ablation wavelength dependency in the range of 5.6-6.7 m using a mid-infrared free electron laser. Nucl. Instrum. Methods Phys. Res. Sect. A Accel. Spectrom. Detect. Assoc. Equip. 2003, 507, 564-568. [CrossRef] 
11. Tiaw, K.S.; Goh, S.W.; Hong, M.; Wang, Z.; Lan, B.; Teoh, S.H. Laser surface modification of poly(epsilon-caprolactone) (PCL) membrane for tissue engineering applications. Biomaterials 2005, 26, 763-769. [CrossRef] [PubMed]

12. Aguilar, C.A.; Lu, Y.; Mao, S.; Chen, S. Direct micro-patterning of biodegradable polymers using ultraviolet and femtosecond lasers. Biomaterials 2005, 26, 7642-7649. [CrossRef] [PubMed]

13. Liu, Y.; Sun, S.; Singha, S.; Cho, M.R.; Gordon, R.J. 3D femtosecond laser patterning of collagen for directed cell attachment. Biomaterials 2005, 26, 4597-4605. [CrossRef] [PubMed]

14. Choi, H.W.; Johnson, J.K.; Nam, J.; Farson, D.F.; Lannutti, J. Structuring electrospun polycaprolactone nanofiber tissue scaffolds by femtosecond laser ablation. J. Laser Appl. 2007, 19, 225-231. [CrossRef]

15. Gaspard, S.; Oujja, M.; de Nalda, R.; Abrusci, C.; Catalina, F.; Bañares, L.; Lazare, S.; Castillejo, M. Submicron foaming in gelatine by nanosecond and femtosecond pulsed laser irradiation. Appl. Surf. Sci. 2007, 253, 6420-6424. [CrossRef]

16. Gaspard, S.; Oujja, M.; de Nalda, R.; Abrusci, C.; Catalina, F.; Bañares, L.; Lazare, S.; Castillejo, M. Nanofoaming in the surface of biopolymers by femtosecond pulsed laser irradiation. Appl. Surf. Sci. 2007, 254, 117-1184. [CrossRef]

17. Gaspard, S.; Forster, M.; Huber, C.; Zafiu, C.; Trettenhahn, G.; Kautek, W.; Castillejo, M. Femtosecond laser processing of biopolymers at high repetition rate. Phys. Chem. Chem. Phys. 2008, 10, 6174-6181. [CrossRef] [PubMed]

18. Gaspard, S.; Oujja, M.; de Nalda, R.; Castillejo, M.; Bañares, L.; Lazare, S.; Bonneau, R. Nanofoaming dynamics in biopolymers by femtosecond laser irradiation. Appl. Phys. A 2008, 93, 209-213. [CrossRef]

19. Oujja, M.; Pérez, S.; Fadeeva, E.; Koch, J.; Chichkov, B.N.; Castillejo, M. Three dimensional microstructuring of biopolymers by femtosecond laser irradiation. Appl. Phys. Lett. 2010, 95, 263703. [CrossRef]

20. Yeong, W.Y.; Lim, K.P.; Ng, G.K.L.; Tan, L.P.; Boey, F.Y.C.; Venkatraman, S.S. Annealing of biodegradable polymer induced by femtosecond laser micromachining. Adv. Eng. Mater. 2010, 12, B89-B93. [CrossRef]

21. Yeong, W.Y.; Yu, H.; Lim, K.P.; Ng, K.L.; Boey, Y.C.; Subbu, V.S.; Tan, L.P. Multiscale topological guidance for cell alignment via direct laser writing on biodegradable polymer. Tissue Eng. Part C Methods 2010, 16, 1011-1021. [CrossRef] [PubMed]

22. Melissinaki, V.; Gill, A.A.; Ortega, I.; Vamvakaki, M.; Ranella, A.; Haycock, J.W.; Fotakis, C.; Farsari, M.; Claeyssens, F. Direct laser writing of 3D scaffolds for neural tissue engineering applications. Biofabrication 2011, 3, 045005. [CrossRef] [PubMed]

23. Lim, Y.C.; Johnson, J.; Fei, Z.; Wu, Y.; Farson, D.F.; Lannutti, J.J.; Choi, H.W.; Lee, L.J. Micropatterning and characterization of electrospun poly( $\varepsilon$-caprolactone)/gelatin nanofiber tissue scaffolds by femtosecond laser ablation for tissue engineering applications. Biotechnol. Bioeng. 2011, 108, 116-126. [CrossRef] [PubMed]

24. Lee, C.H.; Lim, Y.C.; Farson, D.F.; Powell, H.M.; Lannutti, J.J. Vascular wall engineering via femtosecond laser ablation: Scaffolds with self-containing smooth muscle cell populations. Ann. Biomed. Eng. 2011, 39, 3031-3041. [CrossRef] [PubMed]

25. Ortiz, R.; Quintana, I.; Etxarri, J.; Lejardi, A.; Sarasua, J.-R. Picosecond laser ablation of poly-L-lactide: Effect of crystallinity on the material response. J. Appl. Phys. 2011, 110, 094902. [CrossRef]

26. Li, H.; Wen, F.; Wong, Y.S.; Boey, F.Y.; Subbu, V.S.; Leong, D.T.; Ng, K.W.; Ng, G.K.; Tan, L.P. Direct laser machining-induced topographic pattern promotes up-regulation of myogenic markers in human mesenchymal stem cells. Acta Biomater. 2012, 8, 531-539. [CrossRef] [PubMed]

27. Lee, B.L.; Jeon, H.; Wang, A.; Yan, Z.; Yu, J.; Grigoropoulos, C.; Li, S. Femtosecond laser ablation enhances cell infiltration into three-dimensional electrospun scaffolds. Acta Biomater. 2012, 8, 2648-2658. [CrossRef] [PubMed]

28. Wang, H.W.; Cheng, C.W.; Li, C.W.; Chang, H.W.; Wu, P.H.; Wang, G.J. Fabrication of pillared PLGA microvessel scaffold using femtosecond laser ablation. Int. J. Nanomed. 2012, 7, 1865-1873. [CrossRef] [PubMed]

29. Castillejo, M.; Rebollar, E.; Oujja, M.; Sanz, M.; Selimis, A.; Sigletou, M.; Psycharakis, S.; Ranella, A.; Fotakis, C. Fabrication of porous biopolymer substrates for cell growth by UV laser: The role of pulse duration. Appl. Surf. Sci. 2012, 258, 8919-8927. [CrossRef]

30. Li, H.; Wong, Y.S.; Wen, F.; Ng, K.W.; Ng, G.K.; Venkatraman, S.S.; Boey, F.Y.; Tan, L.P. Human mesenchymal stem-cell behaviour on direct laser micropatterned electrospun scaffolds with hierarchical structures. Macromol. Biosci. 2013, 13, 299-310. [CrossRef] [PubMed] 
31. Ortiz, R.; Moreno-Flores, S.; Quintana, I.; Vivanco, M.; Sarasua, J.R.; Toca-Herrera, J.L. Ultra-fast laser microprocessing of medical polymers for cell engineering applications. Mater. Sci. Eng. C Mater. Biol. Appl. 2014, 1, 241-250. [CrossRef] [PubMed]

32. Daskalova, A.; Nathala, C.S.R.; Bliznakova, I.; Stoyanova, E.; Zhelyazkova, A.; Ganz, T.; Lueftenegger, S.; Husinsky, W. Controlling the porosity of collagen, gelatin and elastin biomaterials by ultrashort laser pulses. Appl. Surf. Sci. 2014, 292, 367-377. [CrossRef]

33. Stolberg, K.; Friedel, S.; Kremser, B.; Roehner, M. IR and green femtosecond laser machining of heat sensitive materials for medical devices at micrometer scale. In Proceedings of the Proceeding SPIE, San Francisco, CA, USA, 6 March 2014; Volume 8968, p. 89680E. [CrossRef]

34. Laser Micromachining of Bio-Absorbable Polymers: Impact of the Laser Process Parameters on the Machining Throughput and Quality. Available online: http://www.spectra-physics.cn/assets/client_files/files/ documents/M405\%20paper\%20manuscript_final.pdf (accessed on 1 June 2018).

35. Yada, S.; Terakawa, M. Femtosecond laser induced periodic surface structure on poly-L-lactic acid. Opt. Express 2015, 23, 5694-5703. [CrossRef] [PubMed]

36. Paun, I.A.; Zamfirescu, M.; Mihailescu, M.; Luculescu, C.R.; Mustaciosu, C.C.; Dorobantu, I.; Calenic, B.; Dinescu, M. Laser micro-patterning of biodegradable polymer blends for tissue engineering. J. Mater. Sci. 2015, 50, 923-936. [CrossRef]

37. Jia, W.; Luo, Y.; Yu, J.; Liu, B.; Hu, M.; Chai, L.; Wang, C. Effects of high-repetition-rate femtosecond laser micromachining on the physical and chemical properties of polylactide (PLA). Opt. Express 2015, 23, 26932-26939. [CrossRef] [PubMed]

38. Jun, I.; Chung, Y.; Heo, Y.; Han, H.; Park, J.; Jeong, H.; Lee, H.; Lee, Y.B.; Kim, Y.; Seok, H.; et al. Creating hierarchical topographies on fibrous platforms using femtosecond laser ablation for directing myoblasts behavior. ACS Appl. Mater. Interfaces 2016, 8, 3407-3417. [CrossRef] [PubMed]

39. Daskalova, A.; Nathala, C.S.R.; Kavatzikidou, P.; Ranella, A.; Szoszkiewicz, R.; Husinsky, W.; Fotakis, C. FS laser processing of bio-polymer thin films for studying cell-to-substrate specific response. Appl. Surf. Sci. 2016, 382, 178-191. [CrossRef]

40. Shibata, A.; Yada, S.; Terakawa, M. Biodegradability of poly(lactic-co-glycolic acid) after femtosecond laser irradiation. Sci. Rep. 2016, 6, 27884. [CrossRef] [PubMed]

41. Stępak, B.; Antończak, A.J.; Abramski, K.M. Optimization of femtosecond laser cutting of a biodegradable polymer for medical devices manufacturing. Photonics Lett. Pol. 2016, 8, 116-118. [CrossRef]

42. Umemoto, T.; Shibata, A.; Terakawa, M. Femtosecond laser irradiation of the fluorescent molecules-loaded poly(lactic-co-glycolic acid). Appl. Surf. Sci. 2017, 417, 165-169. [CrossRef]

43. Shibata, A.; Machida, M.; Kondo, N.; Terakawa, M. Biodegradability of poly(lactic-co-glycolic acid) and poly(L-lactic acid) after deep-ultraviolet femtosecond and nanosecond laser irradiation. Appl. Phys. A 2017, 123, 438. [CrossRef]

44. Viertel, T.; Pabst, L.; Olbrich, M.; Ebert, R.; Horn, A.; Exner, H. Generation of nano-voids inside polylactide using femtosecond laser radiation. Appl. Phys. A 2017, 123, 789. [CrossRef]

45. Assaf, Y.; Kietzig, A.-M. Optical and chemical effects governing femtosecond laser-induced structure formation on polymer surfaces. Mater. Today Commun. 2018, 14, 169-179. [CrossRef]

46. Daskalova, A.; Trifonov, A.; Bliznakova, I.; Nathala, C.; Ajami, A.; Husinsky, W.; Declercq, H.; Buchvarov, I. Selective cell response on natural polymer bio-interfaces textured by femtosecond laser. Appl. Phys. A 2018, 124, 207. [CrossRef]

47. Daskalova, A.; Bliznakova, I.; Zhelyazkova, A.; Ostrowska, B.; Trifonov, A.; Buchvarov, I.; Avramov, L.;

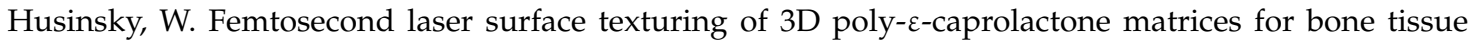
engineering applications. J. Phys. Conf. Ser. 2018, 992, 012048. [CrossRef]

48. Stępak, B.D.; Szustakiewicz, K.; Antończak, A.J. Optimization of femtosecond laser micromachining of polylactide and PLLA/HAp composite. Proc. SPIE 2018, 10520, 105201V. [CrossRef]

49. Sekosan, G.; Vasanthan, N. Morphological changes of annealed poly- $\varepsilon$-caprolactone by enzymatic degradation with lipase. J. Polym. Sci. Part B Polym. Phys. 2010, 48, 202-211. [CrossRef]

50. Vey, E.; Rodger, C.; Meehan, L.; Booth, J.; Claybourn, M.; Miller, A.F.; Saiani, A. The impact of chemical composition on the degradation kinetics of poly(lactic-co-glycolic) acid copolymers cast films in phosphate buffer solution. Polym. Degrad. Stab. 2012, 97, 358-365. [CrossRef] 
51. Wu, L.; Ding, J. Effects of porosity and pore size on in vitro degradation of three-dimensional porous poly(D,L-lactide-coglycolide) scaffolds for tissue engineering. J. Biomed. Mater. Res. A 2005, 75, 767-777. [CrossRef] [PubMed]

52. Ikada, E. Photo- and bio-degradable polyesters photodegradation behaviors of aliphatic polyesters. J. Photopolym. Sci. Technol. 1997, 10, 265-270. [CrossRef]

53. Tsuji, H.; Echizen, Y.; Nishimura, Y. Enzymatic degradation of poly(L-lactic acid): Effects of UV irradiation. J. Polym. Environ. 2006, 14, 239-248. [CrossRef]

54. Hsu, S.-T.; Tan, H.; Yao, Y.L. Effect of laser-induced crystallinity modification on biodegradation profile of poly(L-lactic acid). J. Manuf. Sci. Eng. 2013, 136, 011005. [CrossRef]

55. Farkas, B.; Romano, I.; Ceseracciu, L.; Diaspro, A.; Brandi, F.; Beke, S. Four-order stiffness variation of laser-fabricated photopolymer biodegradable scaffolds by laser parameter modulation. Mater. Sci. Eng. C Mater. Biol. Appl. 2015, 55, 14-21. [CrossRef] [PubMed]

56. Slepička, P.; Michaljaničová, I.; Sajdl, P.; Fitl, P.; Švorčík, V. Surface ablation of PLLA induced by KrF eximer laser. Appl. Surf. Sci. 2013, 283, 438-444. [CrossRef]

57. Oya, K.; Aoki, S.; Shimomura, K.; Sugita, N.; Suzuki, K.; Nakamura, N.; Fujie, H. Morphological observations of mesenchymal stem cell adhesion to a nanoperiodic-structured titanium surface patterned using femtosecond laser processing. Jpn. J. Appl. Phys. 2012, 51, 125203. [CrossRef]

58. Shinonaga, T.; Tsukamoto, M.; Nagai, A.; Yamashita, K.; Hanawa, T.; Matsushita, N.; Xie, G.; Abe, N. Cell spreading on titanium dioxide film formed and modified with aerosol beam and femtosecond laser. Appl. Surf. Sci. 2014, 288, 649-653. [CrossRef]

59. Srinivasan, R.; Lazare, S. Modification of polymer surfaces by far-ultraviolet radiation of low and high (laser) intensities. Polymer 1985, 26, 1297-1300. [CrossRef]

60. Pérez, S.; Rebollar, E.; Oujja, M.; Martín, M.; Castillejo, M. Laser-induced periodic surface structuring of biopolymers. Appl. Phys. A 2013, 110, 683-690. [CrossRef]

61. Toosi, S.; Maradi, S.; Hatzikiriakos, S.G. Fabrication of micro/nano patterns on polymeric substrates using laser ablation methods to control wettability behavior: A critical review. Rev. Adhes. Adhes. 2017, 5, 55-78. [CrossRef]

62. Chu, C.; Wang, Y.; Tai, L.; Wu, L.; Yang, C. Surface deformation of gold nanorod-loaded poly(D,L-lactide-co-glycolide) nanoparticles after near infrared irradiation: An active and controllable drug release system. J. Mater. Chem. 2010, 20, 3260-3264. [CrossRef]

63. Hsu, S.-T.; Yao, Y.L. Effect of drug loading and laser surface melting on drug release profile from biodegradable polymer. J. Appl. Polym. Sci. 2013, 130, 4147-4156. [CrossRef]

64. Ariyasu, K.; Ishii, A.; Umemoto, T.; Terakawa, M. Laser-triggered release of encapsulated molecules from polylactic-co-glycolic acid microcapsules. J. Biomed. Opt. 2016, 21, 085003. [CrossRef] [PubMed]

65. Kerse, C.; Kalaycığlu, H.; Elahi, P.; Çetin, B.; Kesim, D.K.; Akçaalan, Ö.; Yavaş, S.; Aşık, M.D.; Öktem, B.; Hoogland, H.; et al. Ablation-cooled material removal with ultrafast bursts of pulses. Nature 2016, 537, 84-88. [CrossRef] [PubMed]

66. He, F.; Yu, J.; Tan, Y.; Chu, W.; Zhou, C.; Cheng, Y.; Sugioka, K. Tailoring femtosecond 1.5- $\mu$ m Bessel beams for manufacturing high-aspect-ratio through-silicon vias. Sci. Rep. 2017, 7, 40785. [CrossRef] [PubMed]

(C) 2018 by the author. Licensee MDPI, Basel, Switzerland. This article is an open access article distributed under the terms and conditions of the Creative Commons Attribution (CC BY) license (http://creativecommons.org/licenses/by/4.0/). 